\title{
Neplánovaný odklad mateřství do vyššího věku v životní drá- ze českých žen ${ }^{1,2}$
}

\author{
Jitka Slabá ${ }^{3}$ - Jiřina Kocourková - Anna Št’astná \\ Katedra demografie a geodemografie, PřF UK, Praha
}

\begin{abstract}
The Unplanned Postponement of Motherhood to Later Ages in the Life Course of Czech Women. The postponement of fertility has been observed in Czechia since the beginning of the 1990s. This paper employed a mixed-method approach that focused on the various reasons for unplanned postponement. The survey data describes the quantity of the occurrence of unplanned postponement for declared reasons, while the in-depth interviews serve to describe the relationships between the stated reasons. The qualitative research confirms the expectation of the sequential characteristics of postponement; at younger ages, individually-motivated reasoning was found to be common, followed by partner-motivated reasoning and, finally, by health-motivated reasoning. Additionally, individually-motivated reasoning represents the postponement due to the re-evaluation of a plan, while partnermotivated and health-motivated reasoning can be considered as unplanned postponement. Sociológia 2021, Vol. 53 (No. 1: 49-70)

https://doi.org/10.31577/sociologia.2021.53.1.3
\end{abstract}

Key words: Fertility postponement; unplanned postponement; reasons for postponement; mixed-method research; Czech Republic

\section{Úvod}

Rostoucí věk ženy při narození prvního dítěte je významnou součástí změn reprodukčního chování druhé poloviny 20. století (Mills et al. 2011; Sobotka 2017; Kocourková - Št'astná 2021). Od 60. let jej můžeme pozorovat v zemích západní Evropy, od 90. let pak i v zemích střední a východní Evropy. Jednou z možných příčin odkladu rodičovství je proměna sociálních norem a rostoucí individualizace ve společnosti (Lesthaeghe 2010; Polesná - Kocourková 2016). To se projevuje prodlužující se délkou studia a nárůstem zaměstnanosti žen. Plánování reprodukce ve vyšším věku je podpořeno i dostupností efektivních antikoncepčních prostředků (Frejka 2008, Kocourková - Fait 2011) a tlakem současné tržní společnosti na individuální materiální zajištění. Jedinec tak může přehodnocovat své reprodukční plány, nemá-li zajištěn stabilní finanční prŕjjem a/nebo bydlení (Kohler et al. 2002; Mills et al. 2011). Pocit nedostatečného materiálního zajištění může pramenit i z proměn týkajících se utváření a

\footnotetext{
1 Příspěvek vznikl s podporou Grantové agentury ČR, projekt č. 18-08013S Posun rodičovství do vyššího věku: individuálni perspektivy versus společenské náklady a programu Univerzitní výzkumná centra UK UNCE/HUM/018

2 Poděkování: Za spolupráci při prrípravě scénáře a za vedení rozhovoru s informantkami děkujeme Lence Kocourkové a Elišce Sýkorové, které svojí činností přispěly ke zdárné realizaci kvalitativního šetření.

3 Korespondence: Mgr. Jitka Slabá, Doc. RNDr. Jiřina Kocourková, Ph.D., PhDr. Mgr. Anna Št’astná, Ph.D., Přírodovědecká fakulta, Katedra demografie a geodemografie, Univerzita Karlova, Albertov 6, 12843 Praha 2, Česká republika. E-mail: jitka.slaba@natur.cuni.cz; jirina.kocourkova@ natur.cuni.cz; anna.stastna @ natur.cuni.cz
} 
stability partnerských svazků, kdy současně dochází k enormnímu nárůstu mimomanželské plodnosti a k rostoucí intenzitě rozpadu manželství (Van de Kaa 1997). Nicméně i v př́ípadě stabilního partnerského svazku se vztah mezi mužem a ženou pozměnil. Dnešní společnost se vyznačuje rostoucí mírou genderové rovnosti (McDonald 2000; Esping-Andersen 2017), jež může odklad reprodukce prohlubovat $\mathrm{v}$ důsledku ztížení kombinace kariérních a rodinných rolí ženy, které tento proces mohou zpočátku doprovázet.

Spolu s posunem a diverzifikací životních trajektorií jedince (Hofäcker Chaloupková 2014) dochází také k posunu reprodukčních plánů do vyššího věku. Analýzy reprodukčních plánů ovšem ukazují, že se ženám často nedaří tyto plány později realizovat - a to nejen $\mathrm{z}$ hlediska plánovaného počtu dětí, ale ani $\mathrm{z}$ hlediska věku, ve kterém je plánovaly mít (napřr. Berrington 2004; Toulemon - Testa 2005; Kapitány - Spéder 2012). Uvedené naznačuje existenci neplánovaného odkladu, který může v důsledku působit na zvyšující se věk rodiček, potažmo rostoucí bezdětnost. Přes dosavadní znalosti obecných prríčin posunu plodnosti do vyššího věku není oblast neplánovaného odkladu dostatečně prozkoumána. Význam zkoumání neplánovaného odkladu souvisí i se zjištěním, že děti narozené později (later-than-desired), vykazují méně příznivé zdravotní charakteristiky (Hartnett - Margolis 2019).

V Česku, podobně jako na Slovensku, začal proces odkladu plodnosti opožděně, ale zaznamenal dynamičtěšsí nástup (Kocourková - Št’astná 2020; Šprocha - Šídlo 2018). Nejintenzivnější nárůst průměrného věku ženy př́i narození prvního dítěte proběhl v Česku v 90. letech minulého století, kdy došlo ke zvýšení o 2,5 roku (z 22,5 let v roce 1990 na 25 v roce 2000) (Sivková - Hulíková Tesárková 2012). Následně růst zpomalil, ale stále pokračuje, v roce 2018 dosáhl věk prvorodiček 28,4 let (Křest’anová - Kurkin 2019). Přes dosavadní výzkumy prríčin odkladu je vysvětlení procesu stále nedostatečně prozkoumané. Důležitým aspektem se ukazují být neplánované okolnosti, které ženám neumožňují realizovat časový plán.

Pokračování odkladu plodnosti do vyššího věku žen zvyšuje riziko, že se plánované dítě nenarodí a úroveň konečné plodnosti bude klesat. Studie vyspělých zemí, které procesem odkladu plodnosti již prošly, totiž ukazují, že zatímco odložené porody prvního pořadí se $\mathrm{v}$ pozdějším věku $\mathrm{z}$ většiny podaří realizovat, velkou část porodů druhého a především třetího pořadí ženy již nezrealizují (Sobotka et al. 2011). Šprocha (2014) dokládá, že Česko, ale také Slovensko, v tomto ohledu není výjimkou. Bližší pochopení motivací a příčin neplánovaného odkladu může rozšírit východiska pro tvorbu strategií k eliminaci bariér reprodukce či zmírnění jejich dopadů, a to jak na úrovni individuální, tak i na úrovni celospolečenské.

Dosavadní analýza dat z výběrového šetření Ženy 2016 zaměřeného na motivy odkladu plodnosti do vyššího věku žen ukázala, že pozdější časování 
narození prvního i druhého dítěte není vždy plánované (Št’astná et al. 2017; Št’astná et al. 2019). Bylo zjištěno, že mladší generace žen nejen častěji plánují narození prvního dítěte ve vyšším věku než starší generace žen, ale také následně realizaci mateřství častěji odsouvají, a dítě se jim narodí později, než původně plánovaly. Tento následný odklad lze považovat za neplánovaný a je zdůvodňován obtížemi ve čtyřech oblastech: práce a studium, materiální podmínky, nepř́tomnost vhodného partnera a zdravotní komplikace (Št’astná et al. 2017).

Následující analýza využívá možností metodologicky smíšeného výzkumu a dosavadní poznatky získané z kvantitativního dotazníkového šetření rozšiřuje o perspektivu individuální interpretace časování reprodukce získanou z hloubkových rozhovorů. Cílem je zhodnotit, do jaké míry lze pozorovaný posun plodnosti českých žen do vyššího věku vysvětlit narůstajícím podílem nepředvídaných okolností, které lze chápat jako neplánovaný odklad. Bylo zkoumáno, v jaké životní fázi vzniká neplánovaný odklad, zda lze identifikovat jeho př́činy a jak se odlišují od dosud známých příčin posunu časování reprodukce. Př́nos studie spočívá $\mathrm{v}$ zaměření se na vysvětlení neplánovaného odkladu pomocí metodologicky smíšeného výzkumu, který propojuje výsledky kvantitativního a kvalitativního výzkumu (Onwuegbuzie - Collins 2007). Konkrétně byl využit sekvenčně vysvětlující př́stup, kde kvantitativní fáze předchází kvalitativní fázi. Z kvantitativního šetření Ženy 2016 (Št’astná et al. 2017) byly vytipovány respondentky, u kterých byl zjištěn neplánovaný odklad, a tyto respondentky byly následně dále šetřeny $\mathrm{v}$ rámci kvalitativního výzkumu. Individuální rozhovory byly tedy vedeny se specifickou skupinou žen, které plánovaly mít $\mathrm{v}$ určitém věku dítě, ale plány se jim nepodařilo naplnit nebo měly dítě později. Výsledky kvantitativního výzkum ukázaly, že jednotlivá zdůvodnění neplánovaného odkladu plodnosti se mohou vyskytovat současně. Otázkou však je, jakou konkrétní podobu tyto důvody mají, jak spolu vzájemně souvisí a zda jejich výskyt podněcuje př́tomnost dalšího rizika odkladu. K pochopení vzájemných souvislostí ve zdůvodněních neplánovaného odkladu mateřství byl využit kvalitativní výzkum, který detailněji zjištoval př́ičiny odkladu plodnosti prvního pořadí v kontextu životních trajektorií žen.

\section{Teoretická východiska}

Posun rodičovství do vyššího věku se liší z hlediska různých charakteristik žen, jako je věk, dosažené vzdělání, rodinný stav, příjem, místo bydliště a další. Výzkum Wijsen (2002) ukázal, že rostoucí věk je častěji faktorem akcelerujícím plodnost, než že by byl prríčinou odkladu. To je vzhledem k věkové limitaci plodnosti žen pochopitelné. Role manželství v realizaci plodnosti sice oslabuje (Van de Kaa 1997; Lesthaeghe 2010), ale určitý vliv zůstává zachován $\mathrm{v}$ souvislosti $\mathrm{s}$ dosaženým vzděláním ženy. Zatímco ženy s nižším vzděláním 
mají první dítě častěji v nesezdaném svazku, ženy s vyšším vzděláním mají první dítě častěji v manželství (Perelli-Harris et al. 2010; Mikolai et al. 2018). To úzce souvisí se skutečností, že ženy s vyšším vzděláním mají první dítě později (Ní Bhrolcháin - Beaujouan 2012; Neels et al. 2019), a tím tedy mají více času pro vstup do manželství. Se vzděláním souvisí i př́ijem, nebot' vzdělanější jedinec má větší šanci vyššího př́ijmu. Zjištění je v souladu s výsledky potvrzujícími negativní vliv př́ijmu na časování plodnosti, kdy ženy s vyšším příjmovým potenciálem častěji odkládají mateřství do pozdějšího věku (Berrington 2004; Begall 2013). Zároveň může př́ijem, přesněji jeho ztráta, vést $\mathrm{k}$ odkladu plodnosti do pozdějšího věku (Del Bono et al. 2015; Slabá 2020). Místo bydliště souvisí s odlišnou intenzitou šíření hodnotových proměn ve městech a na venkově, v důsledku čehož je evidováno pozdější časování plodnosti v městských oblastech než ve venkovských (Mynarska 2010; Walford - Kurek 2016).

Výše zmíněné proměnné poukazují na charakteristiky jedince, které ovlivňují časování jeho plodnosti. Samotné reprodukční plány a jejich časování odráží individuální postoje, subjektivní normy a vědomou kontrolu chování, které jsou popisovány v rámci teorie plánovaného chování (Dommermuth et al. 2011; Ajzen - Klobas 2013). V současnosti dobře dostupné antikoncepční prostředky umožňují úspěšné naplňování reprodukce, a to především v př́ípadě odkladu plodnosti (Frejka 2008). Hašková (2009) však ve své studii bezdětnosti upozorňuje, že ne všechny okolnosti, které následně ovlivňují realizaci plodnosti, mohou být vnímány jako individuální volby, ale mohou nastat i takové, které realizaci plodnosti znemožňují (kontrastně označené jako nevolby).

Předpoklad plánování reprodukce tak otevírá druhý možný analytický přístup $\mathrm{k}$ odkladu plodnosti, a tím je analýza př́čin odkladu. Řada výběrových šetření zjišt'uje, jaké faktory a jakou roli hrají při rozhodování o časování narození prvního dítěte. Převážná část výzkumů sleduje důvody posunu plodnosti do vyššího věku (Miettinen - Paajanen 2005; Ainsaar - Paajanen 2009; Dey - Fran 2010; Lechnerová 2011; Regushevskaya et al. 2013; Št’astná et al. 2017), jiné práce se zaměřují na sledování důvodů aktuální bezdětnosti (Berrington 2017; Esteve - Trevino 2019) či na sledování důvodů, které hrají roli při rozhodování o časování narození dítěte (Daniluk - Koert 2017). I přes různý způsob dotazování, který znesnadňuje porovnání výsledků, můžeme identifikovat souvislost konkrétních zdůvodnění s věkem ženy.

Věk respondentky hraje významnou roli nejen v časování plodnosti, ale i v neplánovaném odkladu. S rostoucím věkem sledujeme menší výskyt zdůvodnění souvisejících s materiálním zabezpečením (Regushevskaya et al. 2013; Ainsaar - Paajanen 2009; Št’astná et al. 2017; Esteve - Trevino 2019). Naopak roste výskyt zdůvodnění odkladu vzhledem ke zdravotnímu stavu či neplod- 
nosti (Š́tastná et al. 2017; Esteve - Trevino 2019). Zdá se však, že odklad motivovaný nepř́tomností partnera přetrvává rovnoměrně v průběhu celého období plánování plodnosti (Berrington 2017, Št’astná et al. 2017; Esteve Trevino 2019). Dosavadní zjištění poodhalují možnost, že některá zdůvodnění úzce souvisí s věkem, ve své povaze ale neumožňují identifikovat, zda když pomine důvod související s mladším věkem, je plodnost realizována, či zda žena naráží na další překážku realizace plodnosti související s věkem vyšším. Sekvenčnost (tj. dynamická proměna) plánování v závislosti na věku byla pozorována $\mathrm{v}$ odborné literatuře $\mathrm{v}$ př́ípadě plánovaného počtu dětí (Rabušic Chromková Manea 2007; Hayford 2009; Gemmill 2019). Otázkou zůstává, zda bychom tuto sekvenčnost mohli předpokládat i v samotném plánování časování plodnosti.

Nepř́mo se s neplánovaným odkladem plodnosti setkáme i v kvalitativním výzkumu. Slepičková a Bartošová (2008) se zabývaly životními trajektoriemi českých žen, které si přály mít dítě, ale pod vlivem nepř́iznivých okolností svá prání nezrealizovaly. Své informantky definují jako ženy s odloženou plodností $\mathrm{v}$ důsledku absence partnera či fyzické neplodnosti. Výzkumnice zároveň uvádějí, že tyto ženy často kladly důraz na nabytí pracovních zkušeností a vybudování určité pozice na pracovním trhu před mateřstvím. To naznačuje, že plánování plodnosti může mít sekvenční charakter, nebot' nejprve souvisí s realizací na pracovním trhu a následně se zdravotními obtížemi či neprítomností vhodného partnera. Poznatky Slepičkové a Bartošové (2008) se shodují s výsledky týkajícími se britských žen (Cook et al. 2012), které pozdní mateřství nevnímají jako vědomé rozhodnutí a neinterpretují jej jako důsledek vyššího dosaženého vzdělání či kariérní orientace. Jiný kvalitativní výzkum se věnoval typům nesezdaných soužití partnerů, jež jsou rodiči. V souvislosti s plánováním plodnosti zde narážíme na respondentky, které upřednostnily rodičovství před formalizací vztahu sňatkem (Vítečková - Klímová Chaloupková 2014).

Realizaci plodnosti prvního pořadí a potenciální zdůvodnění jejího odkladu můžeme sledovat také optikou výzkumu životních drah (life-course aproach), který umožňuje využití metodologie kvantitativní i kvalitativní (Hašková Dudová 2014). Kvantitativní př́istup zde identifikuje proměny v časování plodnosti i jejich zdůvodnění. Kvalitativní metodologie pak umožňuje hlubší pochopení životní dráhy jedince a identifikaci příčin, které mohou vést k odkladu rodičovství. Založení rodiny je rozhodnutím dvou jedinců, jejichž individuální životní trajektorie se tak nemusí ve stejném období nacházet v ideální konstelaci pro plánování rodičovství. Dudová (2020) poukazuje na skutečnost, že rodiče jedináčků často ve zdůvodnění jednodětnosti argumentují kontextem partnerovy životní dráhy. Další studie pak identifikují faktory ovlivňující otcovskou tranzici v průběhu životního běhu (Kyzlinková - Št’astná 
2018; Št’astná - Kyzlinková 2019), ale také výraznou nejistotu v reprodukčních plánech mladých českých mužů (Kyzlinková - Št’astná 2016).

Následující analýza se zaměřuje na zdůvodnění neplánovaného odkladu plodnosti prvního pořadí, především na vzájemnou časovou souvislost, zda jde o souběžný výskyt faktorů odkladu (kdy odklad je zapř́ičiněn více důvody, jež působí ve stejném čase), či o sekvenční výskyt faktorů odkladu (kdy odklad je nejprve motivován jedním faktorem a po jeho odstranění žena čelí jinému faktoru). V rámci zhodnocení vlivu těchto faktorů z hlediska životní dráhy žen je cílem identifikace důvodů neplánovaného odkladu.

\section{Data a metody}

Analytická část vychází $\mathrm{z}$ dat kvantitativního a kvalitativního šetření realizovaných v letech 2016 a 2019. Šetření Ženy 2016 dotazovalo 1257 českých žen narozených v letech 1966 - 1990 (Št’astná et al. 2017). Koncept neplánovaného odkladu je založen na analýze série otázek zjištujících reprodukční plány a jejich časování. Dotazován byl věk, ve kterém si respondentka plánovala (plánuje $\mathrm{v}$ př́padě bezdětných žen) narození prvního dítěte, a věk, kdy se jí první dítě skutečně narodilo. Zároveň respondentky hodnotily reálné časování narození svého prvního dítěte ve vztahu ke svým reprodukčním plánům. Otázka byla variantní dle toho, zda byla žena $\mathrm{v}$ době šetření bezdětná, či měla dítě/děti: „Když porovnáte věk, ve kterém jste plánovala mít první dítě, a věk, kdy se Vám první dítě skutečně narodilo, je možné říci, že: 1) První dítě se mi narodilo později, než jsem původně chtěla/plánovala. 2) První dítě se mi narodilo ve věku, kdy jsem jej chtěla/plánovala. 3) První dítě se mi narodilo dřive, než jsem původně chtěla/plánovala.“ $\mathrm{V}$ př́ípadě, že se dítě narodilo později, než bylo plánováno $(\mathrm{N}=470)$, byly zjišt'ovány i související důvody. Respondentky vybíraly až tři hlavní důvody odkladu z předložené baterie dvanácti zdůvodnění. Hlavní důvody neplánovaného odkladu jsou kvantitativně zhodnoceny v první analytické části a slouží jako východiska pro kvalitativní výzkum. Cílem bylo ilustrovat vzájemný výskyt různých zdůvodnění neplánovaného odkladu, který je významně častěji deklarován ženami s vysokoškolským vzděláním (Št’astná et al. 2017), a proto do následujícího kvalitativního šetření vstupují s převahou.

Kvalitativní výzkum proběhl $\mathrm{v}$ roce 2019. Informantky byly rekrutovány z žen, které v šetření Ženy 2016 uvedly, že se jim první dítě narodilo později, než původně chtěly/plánovaly. S nabídkou účasti byly osloveny respondentky, které byly $\mathrm{v}$ době kvantitativního šetření mladší 40 let a uvedly alespoň dva hlavní důvody neplánovaného odkladu narození prvního potomka (viz Tabulka č. 3). Celkem bylo osloveno 137 respondentek, z nichž 23 souhlasilo s možnou účastí. Rozhovor byl proveden s 15 ženami, tři ženy si účast ve výzkumu rozmyslely a s pěti se nepodařilo domluvit vhodný termín. Výsledný vzorek 15 
žen reflektuje všechna hlavní zdůvodnění neplánovaného odkladu rodičovství pozorovaná $\mathrm{v}$ kvantitativním šetření. Zahrnuje zároveň ženy $\mathrm{v}$ různých fázích realizace rodičovství - pět žen bylo v době rozhovoru bezdětných (netěhotné, ale plánující alespoň jedno dítě) a deset žen již první dítě mělo (dvě z nich měly dvě děti a jedna byla podruhé těhotná). $Z$ důvodu nesouhlasu některých respondentek nemohly být údaje z kvantitativního a kvalitativního šetření $\mathrm{v}$ analýzách propojeny.

S oporou předem připraveného scénáře s tématy byly realizovány polostrukturované hloubkové rozhovory. Rozhovory probíhaly individuálně v období od 1. listopadu do 15 . prosince 2019 a byly se souhlasem informantek nahrávány a následně přepisovány.

Na začátku rozhovoru byla žena dotázána, kdy poprvé začala uvažovat, že bude mít dítě. Následně pak, zda svoji představu časem pozměnila a jaké důvody ji k tomu vedly. Cílem bylo identifikovat představy o časování rodičovství, jeho vědomé plánování a také cesty $\mathrm{k}$ jeho realizaci. $\mathrm{V}$ průběhu rozhovoru byla respondentka požádána, aby doplnila i kontextuální informace o prrítomnosti partnera či finanční situaci, což následně umožnilo pochopit vzájemné souvislosti př́ícin odkladu.

Po úvodním poslechu rozhovorů byly analyzovány jejich přepisy následujícím způsobem: 1) identifikace pasáží o časových plánech narození prvního dítěte, 2) identifikace argumentovaných důvodů vedoucích ke změnám plánů či přímo $\mathrm{k}$ jejich nenaplnění, 3) kódování témat s důrazem na plánování, podmínky založení rodiny a na překážky realizace plodnosti. Z rozhovorů bylo identifikováno, $\mathrm{v}$ jakém období se zmiňovaná témata vyskytovala a zda se vyskytovala samostatně, či společně. Následnou kombinací všech výpovědí, byl vypozorován vzorec sekvenčnosti zdůvodnění odkladu. Informantky jsou v textu uváděny pod pseudonymy, je u nich uveden dosažený věk v roce 2019, počet dětí a věk při narození prvního dítěte.

\section{Hlavní příčiny neplánovaného odkladu v kvantitativní optice}

V šetření Ženy 2016 byl 470 respondentkami deklarován neplánovaný odklad narození prvního dítěte a jeho hlavní důvody. Tabulka č. 1 uvádí kompletní seznam zdůvodnění, jejich absolutní výskyt v hlavních třech důvodech odkladu, relativní výskyt zdůvodnění mezi odkládajícími respondentkami, průměrný věk respondentek v roce 2016, které uvedly dané zdůvodnění, a průměrný věk, ve kterém respondentky s daným zdůvodněním plánovaly narození prvního dítěte. Nejčastějšími důvody neplánovaného odkladu jsou nepřítomnost vhodného partnera (téměř $36 \%$ respondentek), delší doba trvání otěhotnění (25\%) a zdravotní stav respondentky či jejího partnera (20\%).

Respondentky, které zdůvodňují odklad vlastním nebo partnerovým zdravotním stavem, byly v průměru v době šetření ve věku 37,4 let, zatímco ty, co 
uvedly odklad kvůli studiu, byly v průměru ve věku 31,2 let (Tabulka č. 1). Plánovaný věk narození prvního dítěte se ale s ohledem na důvody odkladu lišil minimálně (průměrný věk mezi 26 a 27 lety). Výjimkou je zdůvodnění s ohledem na zájmy respondentky (průměr 29 let). $Z$ toho lze usoudit, že věk, ve kterém respondentky plánovaly narození prvního dítěte, pravděpodobně nesehrává ve vysvětlení neplánovaného odkladu významnější roli.

Tabulka č. 1: Př̀ehled hlavních zdůvodnění neplánovaného odkladu v souvislosti s dalšími charakteristikami respondentek

\begin{tabular}{|c|c|c|c|c|c|}
\hline \multicolumn{2}{|c|}{ Důvody odkladu } & \multirow{2}{*}{$\begin{array}{c}\begin{array}{c}\text { Výskyt mezi } \\
\text { hlavními } \\
\text { důvody }\end{array} \\
168\end{array}$} & \multirow{2}{*}{$\begin{array}{c}\begin{array}{c}\text { Podíl } \\
\text { z odkládajících }\end{array} \\
35.7\end{array}$} & \multirow{2}{*}{$\begin{array}{c}\begin{array}{c}\text { Průměrný věk } \\
\text { respondentek } \\
\text { v roce } 2016\end{array} \\
34.4\end{array}$} & \multirow{2}{*}{ 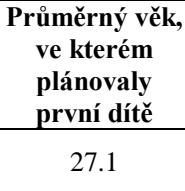 } \\
\hline $\mathbf{R} 1$ & $\begin{array}{l}\text { Neměla jsem vhodného } \\
\text { partnera }\end{array}$ & & & & \\
\hline $\mathbf{R 2}$ & $\begin{array}{l}\text { Otěhotnění nám trvalo déle, } \\
\text { než jsem předpokládala }\end{array}$ & 116 & 24.7 & 36.5 & 26.3 \\
\hline $\mathbf{R 3}$ & $\begin{array}{l}\text { Můj nebo partnerův zdravotní } \\
\text { stav }\end{array}$ & 94 & 20.0 & 37.4 & 26.3 \\
\hline $\mathbf{R 4}$ & $\begin{array}{l}\text { Rozchod/rozvod s tehdejším } \\
\text { partnerem }\end{array}$ & 82 & 17.4 & 34.1 & 26.7 \\
\hline R5 & Nevyhovující bytová situace & 71 & 15.1 & 34.1 & 26.4 \\
\hline R6 & $\begin{array}{l}\text { Nedostatek peněz } \\
\text { Moje studium/zvyšování }\end{array}$ & 66 & 14.0 & 32.4 & 26.5 \\
\hline $\mathbf{R 7}$ & $\begin{array}{l}\text { kvalifikace neumožňovalo } \\
\text { mít dítě dř́ve }\end{array}$ & 61 & 13.0 & 31.2 & 27.0 \\
\hline $\mathbf{R 8}$ & $\begin{array}{l}\text { Moje práce a profesní aktivity } \\
\text { neumožňovaly mít dítě dříve }\end{array}$ & 51 & 10.9 & 32.4 & 27.8 \\
\hline R9 & $\begin{array}{l}\text { Můj partner si přál mít dítě } \\
\text { později }\end{array}$ & 47 & 10.0 & 34.4 & 26.6 \\
\hline R10 & $\begin{array}{l}\text { Obava z nezaměstna- } \\
\text { nosti/ztráty zaměst- } \\
\text { nání/zhoršení pracovní pozice }\end{array}$ & 42 & 8.9 & 32.8 & 27.0 \\
\hline R11 & Jiný důvod & 38 & 8.1 & 35.7 & 26.5 \\
\hline $\mathbf{R} 12$ & $\begin{array}{l}\text { Moje zájmy neumožnovaly } \\
\text { mít dítě dříve }\end{array}$ & 16 & 3.4 & 33.5 & 28.8 \\
\hline
\end{tabular}

Pozn.: Respondentka uvedla alespoň jeden a maximálně tři hlavní důvody odkladu z nabízených výroků Zdroj: Šetření Ženy 2016, nevážená data $(\mathrm{N}=470)$

Tabulky č. 2 a č. 3 identifikují důvodů uváděné společně a naznačují tak jejich možnou provázanost. Nejčastěji jsou společně uváděny výroky z podobné oblasti života, avšak vyskytují se i ostatní kombinace. V príípadě odkladu motivovaného z více oblastí je dominantní souvislost partnerských zdůvodnění, která se v případě kombinací tř́i oblastí důvodů vyskytují nejčastěji společně $\mathrm{s}$ důvody studijně-pracovními a materiálními $(\mathrm{N}=15)$, v př́ípadě dvojice důvodů je nejčetnější jejich kombinace s materiálním zdůvodněním $(\mathrm{N}=30)$ a samostatně stojí za 124 odklady (Tabulka č. 2). Pouhých 137 respondentek uvedlo důvod odkladu založení rodiny z více oblastí. 
Tabulka č. 2: Výskyt počtu jednotlivých unikátních zdůvodnění neplánovaného odkladu narození prvního dítěte

\begin{tabular}{ll}
\hline Počet respondentů se třemi unikátními zdůvodněními & $\mathbf{2 5}$ \\
studijně-pracovní, materiální a partnerské zdůvodnění & 15 \\
studijně-pracovní, partnerské a zdravotní zdůvodnění & 5 \\
materiální, partnerské a zdravotní zdůvodnění & 4 \\
studijně-pracovní, materiální a zdravotní zdůvodnění & 1 \\
& \\
Počet respondentů se dvěma unikátními zdůvodněními & $\mathbf{1 1 2}$ \\
materiální a partnerské zdůvodnění & 30 \\
partnerské a zdravotní zdůvodnění & 28 \\
studijně-pracovní a partnerské zdůvodnění & 23 \\
studijně-pracovní a materiální zdůvodnění & 13 \\
materiální a zdravotní zdůvodnění & 10 \\
studijně-pracovní a zdravotní zdůvodnění & 8 \\
& \\
Počet respondentů s jedním unikátním zdůvodněním & $\mathbf{3 1 2}$ \\
partnerské zdůvodnění & 124 \\
zdravotní zdůvodnění & 108 \\
studijně-pracovní zdůvodnění & 48 \\
materiální zdůvodnění & 32 \\
Respondenti s nezahrnutými zdůvodněními (R11 a R12) & \\
Celkem & $\mathbf{2 1}$
\end{tabular}

Poznámka: Jako unikátní zdůvodnění jsou považovány následující skupiny výroků z Tabulky č. 1: partnerské (R1 + R4 + R9), zdravotní (R2 + R3), materiální (R5 + R6) a studijně-pracovní (R7 + R8 + R9). Zdroj: šetření Ženy 2016, nevážená data $(\mathrm{N}=470)$

Detailní pohled potvrzuje, že uváděné důvody jsou často z podobných oblastí života (Tabulka č. 3). V případě, že žena neměla vhodného partnera, pak nejčastěji zároveň uvedla mezi hlavními př́ičinami také rozchod či rozvod s tehdejším partnerem (35\%). Vztah těchto zdi̊vodnění lze nahlížet i ze strany rozchodu a rozvodu $\mathrm{s}$ tehdejším partnerem, kdy $71 \%$ zároveň uvedlo mezi hlavními důvody odkladu i absenci vhodného partnera. Stejně tak je patrný vzájemný vztah druhého a třetího nejčastěji uváděného důvodu - delší doby trvání otěhotnění a zdravotního stavu. Další dvojicí je nevyhovující bytová situace a nedostatek peněz. Vzájemnou provázanost zdůvodnění lze pak vysledovat i v př́ípadě výroků týkajících se studia či zaměstnání. 
Tabulka č. 3: Vzájemný výskyt důvodů neplánovaného odkladu

\begin{tabular}{|c|c|c|c|c|c|c|c|c|c|c|c|c|c|}
\hline \multirow{2}{*}{\multicolumn{2}{|c|}{$\begin{array}{l}\text { Důvody odkladu } \\
\text { (zkrácené znění) }\end{array}$}} & \multicolumn{12}{|c|}{$\begin{array}{c}\text { Související zdůvodnění odkladu (podíl mezi hlavními důvody, řádková } \\
\text { procenta) }\end{array}$} \\
\hline & & \multirow[t]{2}{*}{$\mathbf{R} 1$} & \multirow{2}{*}{$\frac{\mathbf{R 2}}{7.1}$} & \multirow{2}{*}{$\frac{\mathbf{R 3}}{11.3}$} & \multirow{2}{*}{$\frac{\mathbf{R 4}}{34.5}$} & \multirow{2}{*}{$\frac{\mathbf{R 5}}{8.9}$} & \multirow{2}{*}{$\frac{\mathbf{R 6}}{13.1}$} & \multirow{2}{*}{$\frac{\mathbf{R 7}}{7.7}$} & \multirow{2}{*}{$\frac{\mathbf{R 8}}{7.1}$} & \multirow{2}{*}{$\frac{\mathbf{R 9}}{6.5}$} & \multirow{2}{*}{$\frac{\mathbf{R} 10}{6.5}$} & \multirow{2}{*}{$\frac{\mathbf{R} 11}{2.4}$} & \multirow{2}{*}{$\frac{\mathbf{R} 12}{3.0}$} \\
\hline R1 & $\begin{array}{l}\text { Neměla } \\
\text { partnera }\end{array}$ & & & & & & & & & & & & \\
\hline R2 & $\begin{array}{l}\text { Delší doba } \\
\text { trvání } \\
\text { otěhotnění }\end{array}$ & 10.3 & & 39.7 & 4.3 & 4.3 & 5.2 & 2.6 & 3.4 & 3.4 & 1.7 & 4.3 & 0.0 \\
\hline $\mathbf{R 3}$ & Zdravotní stav & 20.2 & 48.9 & & 11.7 & 6.4 & 4.3 & 7.4 & 2.1 & 5.3 & 2.1 & 3.2 & 0.0 \\
\hline R4 & $\begin{array}{l}\text { Rozchod/ } \\
\text { rozvod }\end{array}$ & 70.7 & 6.1 & 13.4 & & 8.5 & 7.3 & 4.9 & 2.4 & 6.1 & 2.4 & 4.9 & 0.0 \\
\hline $\mathbf{R 5}$ & Bytová situace & 21.1 & 7.0 & 8.5 & 9.9 & & 43.7 & 8.5 & 7.0 & 11.3 & 11.3 & 2.8 & 4.2 \\
\hline R6 & $\begin{array}{l}\text { Nedostatek } \\
\text { peněz }\end{array}$ & 33.3 & 9.1 & 6.1 & 9.1 & 47.0 & & 7.6 & 9.1 & 9.1 & 13.6 & 4.5 & 1.5 \\
\hline $\mathbf{R 7}$ & Studium & 21.3 & 4.9 & 11.5 & 6.6 & 9.8 & 8.2 & & 32.8 & 11.5 & 18.0 & 3.3 & 6.6 \\
\hline R8 & Profese & 23.5 & 7.8 & 3.9 & 3.9 & 9.8 & 11.8 & 39.2 & & 0.0 & 27.5 & 3.9 & 11.8 \\
\hline R9 & $\begin{array}{l}\text { Partnerovo } \\
\text { přání }\end{array}$ & 23.4 & 8.5 & 10.6 & 10.6 & 17.0 & 12.8 & 14.9 & 0.0 & & 4.3 & 2.1 & 4.3 \\
\hline R10 & $\begin{array}{l}\text { Ztráta } \\
\text { zaměstnání }\end{array}$ & 26.2 & 4.8 & 4.8 & 4.8 & 19.0 & 21.4 & 26.2 & 33.3 & 4.8 & & 2.4 & 9.5 \\
\hline R11 & Jiný důvod & 10.5 & 13.2 & 7.9 & 10.5 & 5.3 & 7.9 & 5.3 & 5.3 & 2.6 & 2.6 & & 2.6 \\
\hline R12 & Zájmy & 31.3 & 0.0 & 0.0 & 0.0 & 18.8 & 6.3 & 25.0 & 37.5 & 12.5 & 25.0 & 6.3 & \\
\hline
\end{tabular}

Zdroj: Šetření Ženy 2016, nevážená data $(\mathrm{N}=470)$

Kvantitativní šetření identifikuje zdůvodnění uváděná společně, nespecifikuje ale jejich časovou souvislost. K hlubšímu porozumění vzájemným souvislostem mezi důvody neplánovaného odkladu by měla přispět kvalitativní analýza.

\section{Neplánovaný odklad plodnosti prvního pořadí v kvalitativním šetření}

Časování plodnosti prvního pořadí bylo zkoumáno na základě individuálních rozhovorů $\mathrm{s}$ ženami, které si v určitém věku dítě plánovaly, ale nepodařilo se jim tento časový plán naplnit. Cílem bylo rozklíčovat, proč se jim nepodařilo mít dítě podle plánu a jak spolu souvisí faktory, které se na neplánovaném odkladu pravděpodobně podílely.

\section{Zdůvodnění v závislosti na životní etapě}

V jednotlivých životních etapách očekáváme odlišná zdůvodnění časování mateřství. Ženy mohou plánovat dítě v nižším věku, avšak s prodlužujícím se studiem plán přehodnotí a odloží až za ukončení studia. 
„V dnešni době je to těžký, většina žen prostě studuje a myslím si, že málokterá je schopná skloubit studium s rodičovstvím, takže je sice hezké, že se řiká, že ta nejlepši doba na to mít to ditě je v těch 25, maximálně 25 letech, ale že v dnešním světě je to ve výsledku dost nereálný. " (Linda, 31 let, jedno ditě, prvni ditě ve 29 letech)

V kvantitativním šetření jsou tyto důvody argumentovány jako neplánovaný odklad, kvalitativní rozhovory ale ukazují, že může jít o dobrovolné přehodnocení plánu. Respondentky uvádí, že po studiu toužily získat pracovní zkušenosti ještě před založením rodiny. Motivace jsou různé: může jít o touhu po praktickém využití nabytých studijních znalostí či může jít o motivaci materiální (např. získat nárok na peněžitou pomoc v mateřství).

„Chtěla jsem ziskat nějakou praxi. Jednak tam byla ta podminka, že člověk musi mit těch 180 dni, aby dostal mateřskou, což jsou skoro dva roky, tak jsem to chtěla mít splněný. " (Eva, 33 let, dvě dèti, prvni dítě ve 31 letech)

„Já jsem vlastně nastoupila do práce a zjistila jsem, že nic neumím, což je asi problém každýho studenta, že máte pocit, že do vás drilujou všechno možný a že těch vědomostí už víc mit nemũžete, a pak př́dete do reálu a zjistite, že vlastně neumite vůbec nic <...> takže jsem si řikala, že jestli se to vlastně odložilo kvůli tomu studiu, potřebuju aspoň si nějak zažit tu práci, protože jestli ted’ pudu na tu rodičovskou, tak všechno zapomenu a všechno to bude $k$ ničemu. " (Linda, 31 let, jedno dítě, prvni ditě ve 29 letech)

Další možností odkladu kvůli práci může být nepř́mý tlak ze strany zaměstnavatele či touha realizovat se v zaměstnání, kdy nově získaná role respondentku bavila, a myšlenky na dítě se tak upozadily.

„Já jsem mohla jít samozřejmě na mateřskou, kdybych řekla, tak oni by mě museli pustit, ale tak jako morálně nebo nevím, nějak pocitově, když jsem jim slibila, že jim vypomůžu, tak mi bylo hloupý po pár měsicich ríct, že končím. “ (Tereza, 36 let, jedno ditě, prvni ditè ve 31 letech)

\section{Zdůvodnění nezávislé na životní etapě}

Nezávisle na věku a životní etapě se v rozporu s přáním respondentky mít dítě vyskytuje nesouhlas právě př́tomného partnera. $V$ některých př́ípadech došlo $\mathrm{k}$ rozpadu takového svazku, $\mathrm{v}$ jiných partner časem změnil názor. Nesouhlas je spojován s partnerovým pocitem, že dítě zatím nedokážou materiálně zabezpečit, že na dítě mají ještě čas, a se skutečností, že partner má dítě z předchozího vztahu a další si nepřeje.

„২...> s partnerem, kterej už dvě děti měl a ř́kal, že tři děti jsou v tehdejší době prežitek, že z finančniho hlediska by se jako neuživily nebo nebylo by se 
možný o ně postarat. Takže asi možná $i v$ těch 25 jsem prèejejšlela nad tím, že bych jako dèti neméla. " (Renata, 40 let, bezdětná)

Některé informantky deklarovaly obtíže v navazování partnerského vztahu a dlouhé období pochybností o možnosti nalézt životního partnera.

„U mě bylo to, jestli ty děti vỉbec budou. Já jsem od dètství tak nějak nezapadala, špatně navazuju kontakty s lidma. <...> vždycky tak nějak čním bokem a lidi se se mnou jako scházejí, maji mě za kamarádku, ale ti chlapi se mi prostě vždycky vyhýbali, takže vždycky bylo jasné, že abych já si našla partnera, takže to bude krapet komplikované. "(Katka, 40 let, dvě děti, prvni dítě ve 36 letech)

Jiné respondentky zmínily i roli okolí. Domnívaly se, že kdyby vrstevníci měli děti dř́ve, pak by se i ony staly dříve rodiči.

„<...> co mám kamarádky, tak všechny mají děti až po třicítce, takže to asi člověka taky ovlivní, jako myslím si, že kdyby mélo kolem mě víc lidí děti, tak by mě to asi taky tak nějak nutilo, pochovala bych si někde miminko a chtěla bych ho mit taky doma. <smich> " (Simona, 34 let, jedno ditè, prvni ditě ve 31 letech)

\section{Společný výskyt faktorů odkladu}

Zdůvodnění neplánovaného odkladu se často vyskytují ve vzájemných souvislostech. Priorita dokončení studia může být motivována vizí budoucího lepšího materiálního zabezpečení. V průběhu studia jsou respondentky odkázány na malé přivýdělky a nepovažují svoji materiální situaci (př́ijem a bydlení) za vyhovující pro početí potomka. Vytvoření stabilního zázemí je uváděno jako podmínka realizace reprodukčních plánů, a plány jsou tak přehodnoceny.

„Jsme vlastně neměli něco vlastniho, bydleli jsme v garsonce, platili jsme podnájem. Takže to je taky takový blbý, když studujete, máte nějakej studentskej príjem, $<\ldots>$ a pořídit si do toho ještě ditě je takový divoký. " (Iva, 33 let, jedno dítě, prvni ditè ve 27 letech)

„Když jsem skončila v 34 〈studium〉, tak pak jsem si teprve začala hledat nějakou práci, která bude lépe placená, která mě uživí a budu si moct vybudovat nějaké zázemí. No a tím se to všechno posunulo." (Hana, 41 let, bezdètná)

Nepř́íznivá finanční situace neumožňující pořízení vlastního bydlení může vést $\mathrm{k}$ nesouhlasu partnera, který by měl dítě raději až později. Stejně tak může partnerův nesouhlas souviset s práním, aby partnerka či př́padně oba nejprve dostudovali a našli si stabilní zaměstnání. 
„A hlavně on nechtěl mit dèti tak brzo <...> A hlavně taky finanční situace tomu neodpovídala, aby sme mohli mít ditě a prestěhovat se. Takže tyhle dvě základni věci si myslím, že to hodně oddálily." (Daniela, 34 let, jedno dítě, prvni dítě ve 33 letech)

Studium či realizace $\mathrm{v}$ zaměstnání mohou ovšem souviset $\mathrm{s}$ nepřítomností partnera, se kterým by informantka rodinu založila. Nepř́tomnost partnera se tak ve výpovědích informantek vyskytuje $\mathrm{v}$ roli, kdy by plodnost rády realizovaly, a nemají s kým, a již tedy nedobrovolně své plány odkládají.

„Ale prvni <dité> jsem měla 2015, takže to mi bylo 31 let vlastně, že beru ten plán jakoby splněnej, $i$ když bych klidně už dva roky předtím třeba měla ditěe, ale neměla jsem k tomu partnera." (Jana, 36 let, dvě děti, prvni dítě ve 32 letech)

„Tak já jsem hlavně byla opravdu dlouho sama, jo? Já jsem neměla vlastně s kým ty děti mit. " (Katka, 40 let, dvě dèti, prvni ditě ve 36 letech)

\section{Dalš́ související faktory odkladu}

Vedle předpokladu stabilního zázemí se vyskytuje i přání respondentky mít nejprve svatbu a až pak děti. Nicméně v př́padě respondentčina pocitu, že už jí tzv. tikají biologické hodiny, může být přání svatby upozaděno a nejprve přichází narození prvního dítěte $\mathrm{s}$ tím, že možnost mít svatbu není věkově limitována, zatímco plodnost ano.

„Tak jsem to brala jako zásadni věc mít děti až po svatbě, ale člověk to prostě přehodnotí. Pak začnou být důležitějši věci, obava o zdraví, který si člověk myslí, že... já jsem si myslela, že jsem v pořádku, ale to všichni zjistí, až když se jim nedaři otěhotnět dejme tomu, takže pak jsem to smazala ze svýho plánu, že se dá líp odsunout svatba než děti. To jsem přehodnotila zásadně." (Jana, 36 let, dvě děti, prvni ditě ve 32 letech)

Touhu po svatbě můžeme vnímat jako indikátor tradičních hodnot. V souvislosti s tradičními hodnotami, které respondentky artikulují s ohledem na svůj původ z menšího města či vesnice, se vyskytují i jakési povzdechy nad životem ve velkoměstě, který je bud' zapříčiněn studiem, či stěhováním za partnerem. Velkoměstu je přičítána anonymita a široké možnosti seberealizace, kterým pak některé ženy přičítají svoji bezdětnost či pozdější plodnost.

„Jo, tak musím ř́ct, že když je člověk v Praze, tak tady si nepř́de sám, protože tady to je velký město... <...> Ale jak prijiedete $k$ nám na vesnici, tak tam všichni mi vrstevníci maji děti. < ...> A tam najednou, i když jsou to vaši známí, vaši kamarádi, tak ale už mají svoji rodinu a vy se tam citite hrozně sama. 
$<\ldots>$ Kdybych zůstala na vesnici, tak si už dávno někoho najdu. Tady se sama necitím. "(Hana, 41 let, bezdètná)

Posledním významným faktorem odkladu byly ve výpovědích respondentek zdravotní komplikace, se kterými se respondentka povětšinou potýká až ve chvíli, když už nic jiného realizaci plánu narození prvního dítěte nebrání, a dochází tak v důsledku zdravotních obtíží k neplánovanému odkladu.

„,Takže vlastně jednak to, že človék čekal a myslel si, že pak to bude jako hned nebo bude to bez problémuं, tak se k tomu pridaly zdravotni problémy. "(Linda, 31 let, jedno dité, prvni ditě ve 29 letech)

„No samozřejmě tam byly nějaký takový ty průpovidky <ze strany rodiny>, že prostě jako, že už jsem stará, že bych měla mit děti a že to odkládám, ale nikdy asi nikdo neřešil to, že ty děti nemám ze zdravotnich dưvodů, 〈...〉 Takže všichni jako by spiš rejpali, že nemáme děti kvưli tomu, že nemáme čas nebo že prostě je asi nechceme, ale nikdy asi nikdo neřešil to, že by tam mohly bejt nějaký jiný di̊vody. " (Renata, 40 let, bezdětná)

\section{Sekvenčnost zdůvodnění odkladu}

Výpovědi respondentek naznačují čtyři možné důvody, které mohou být u zrodu vícečetného odkladu: (1) nejprve si přály dostudovat (a př́padně i získat nějakou praxi), (2) neměly partnera nebo (3) partnerská neshoda v názoru na to mít dítě, a (4) zdravotní důvody. Odklad $\mathrm{z}$ důvodu studia a práce jsou ve vzájemné vazbě a může po nich následovat další důvod odkladu v podobě nepř́tomnosti partnera či neshody s partnerem. Neshoda s partnerem o založení rodiny může vést $\mathrm{k}$ rozpadu partnerského svazku a tím se opětovně vyskytuje odklad v souvislosti s nepřítomností partnera. $V$ príípadě nového partnera může opětovně dojít k neshodám ohledně plánování rodičovství. Následně, je-li př́ítomen partner a panuje-li shoda na založení rodiny, může být další odklad zapříčiněn delší dobu trvání početí či zdravotními komplikacemi. Zjednodušené shrnutí výsledků kvalitativního výzkumu nabízí Schéma č. 1, přičemž ne všemi etapami musí žena projít. Je nutné připomenout, že partnerův nesouhlas či jeho nepř́tomnost může studiu předcházet, nicméně může přetrvávat i po dokončení studia. Partnersky motivovaný odklad se může vyskytovat ve všech etapách odkladu mateřství, nejdůležitější roli ale sehrává v daném schématu jako mezičlánek. Nedostatečné materiální zabezpečení nebylo zařazeno do schématu jako samostatný důvod odkladu, nebot' se většinou vyskytuje společně s odkladem zdůvodněným studiem či nesouhlasem partnera. 
Schéma č. 1: Sekvenční zobrazení důvodů odkladu

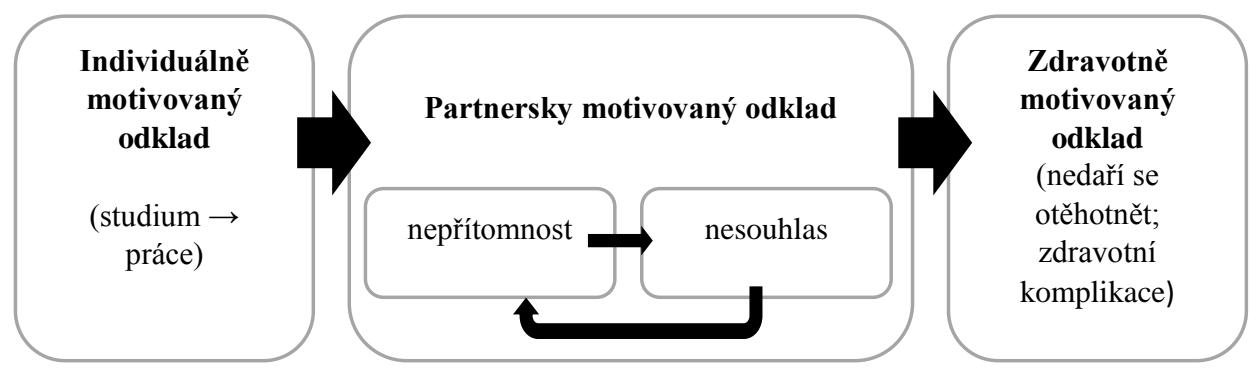

Přehodnocení plánu vs. neplánovaný odklad

Kvantitativní část, vycházející z deklarace neplánovaného odkladu respondentkami samotnými, poukazovala na širokou škálu důvodů odkladu. Kvalitativní výzkum ovšem poodhalil skutečnost, že tento „neplánovaný“ odklad je potřeba vnímat dvojí optikou. $Z$ výpovědí respondentek vyznívá, že mají určité vstupní představy o tom, co by měly mít před založením rodiny. Artikulovanými podmínkami je mít ukončené studium, mít pracovní zkušenost a být materiálně zajištěna (především vyhovující bydlení). Pokud některá z individuálně stanovených podmínek není naplněna, pak respondentka z vlastního rozhodnutí plodnost dobrovolně odkládá a nemusí takový odklad vnímat jako neplánovaný. Jedná se spíše o přehodnocení původního plánu.

Zcela odlišný odklad ovšem nastává ve chvíli, kdy respondentka naplňuje své individuální podmínky pro založení rodiny a dítě si již skutečně přeje mít, přesto $\mathrm{z}$ různých důvodů nemůže. Velmi významným prvkem je $\mathrm{v}$ tu chvíli nepř́tomnost vhodného partnera, partnerův nesouhlas mít děti či partnerovo prání ještě počkat. Tyto obtíže mohou vyústit $\mathrm{v}$ rozpad partnerského svazku a následně časově náročné ustanovení nového vztahu. Další obtíží jsou zdravotní komplikace, at' už respondentky, nebo jejího partnera, které prř́mo nebo nepřímo znemožňují početí. Jak partnerskou neshodu, tak zdravotní potíže nemá respondentka již plně ve své režii a dochází zde z jejího pohledu k ryze neplánovanému odkladu plodnosti.

Vrátíme-li se zpět k sekvenčnímu modelu odkladu plodnosti (Schéma č. 1), pak individuálně motivovaný odklad lze definovat spíše jako racionální přehodnocení plánu, zatímco následující partnersky motivovaný odklad a zdravotně motivovaný odklad jsou spíše př́činami neplánovaného odkladu.

\section{Diskuze}

Cílem bylo podrobněji prozkoumat časování narození prvního dítěte v individuálním životním kontextu žen se zaměřením na důvody odkladu a identifikování jeho neplánované části. Výběrové šetření Ženy 2016 (Št’astná et al. 
2017), umožnilo identifikovat důvody deklarovaného neplánovaného odkladu a tím přispět $\mathrm{k}$ hlubšímu porozumění překážkám, které narušují původní časové plány. Šetření bylo zaměřené na generace českých žen narozené mezi lety 1966 až 1990, u kterých pozorujeme odklad plodnosti (Kurkin et al. 2018; Šprocha et al. 2018).

Výchozí kvantitativní analýza dat z výzkumu Ženy 2016 poukázala na vzájemné provázání zdůvodnění neplánovaného odkladu. Toto šetření však neumožňuje přesně určit, zda se zdůvodnění vyskytují jednotlivě či ve stejné životní etapě. Za tímto účelem byl zrealizován kvalitativní výzkum, kterého se zúčastnilo 15 respondentek vybraných na základě kvantitativního výzkumu. V obou výzkumech se potvrdila př́má souvislost rozchodu s partnerem a následná nepř́itomnost vhodného partnera a stejně tak souvislost delší doby trvání otěhotnění a zdravotních obtíží jednoho partnerů. Dalším důležitým zjištěním z kvalitativního výzkumu bylo, že na původně deklarovaný neplánovaný odklad lze nahlížet dvojí optikou - jako na přehodnocení plánu a jako na neplánovaný odklad, kdy žena neodkládá plodnost dobrovolně, a nelze tedy odklad vnímat jako její volbu.

Plánování rodiny odráží individuální postoje a normy, které dle teorie plánovaného chování ovlivňují také reprodukční chování jedince (Dommermuth et al. 2011; Ajzen - Klobas 2013). Odklad plodnosti až po dokončení studia a získání pracovní praxe byl pozorován již Slepičkovou a Bartošovou (2008). I když se tyto důvody v kvantitativním šetření zdály být přičinou neplánovaného odkladu, kvalitativní výzkum ukázal, že jde spíše o důvody $\mathrm{k}$ přehodnocení plánu samotného, a jde tak o projev individuální volby ženy (Hašková 2009). To souvisí i s doloženým pozorováním, že odklad plodnosti je vědomě ovlivněn prodlužováním doby vzdělávání (Ní Bhrolcháin - Beaujouan 2012; Neels et al. 2019). Vědomý odklad zdůvodněný studiem a prací můžeme vnímat jako projev reakce na ekonomickou nejistotu, se kterou se v rané dospělosti dnešní jedinec potýká a bere ji v úvahu, když plánuje založení rodiny (Kohler et al. 2002).

Partnersky motivovaný odklad je považován za složitě ovlivnitelnou okolnost (Slepičková - Bartošová 2008; Cooke et al. 2012) a jako obtížně řešitelný ze strany ženy jej označují i informantky v našem výzkumu. Můžeme jej tedy vnímat jako projev nevolby (Hašková 2009) indikující neplánovaný odklad. $\mathrm{V}$ př́padě, že nejde přímo o neprítomnost partnera, ale pouze o neshodu s partnerem, zda či kdy založit rodinu, je pak partnerův nesouhlas často př́itomen spolu s nedostatečným materiálním zabezpečením páru a informantky usuzují, že v př́ípadě lepší finanční situace by partnerův nesouhlas nebyl tak silný. To koresponduje s poznatky Dudové (2020), že rozhodnutí o počtu a časování společných dětí je výsledkem životní trajektorie jak ženy, tak jejího partnera. 
Některé ženy deklarovaly, že je pro ně důležité před založením rodiny uzavřít s partnerem sňatek. Můžeme se ale také stejně jako Vítečková a Klímová Chaloupková (2014) setkat s prioritizací mateřství před sňatkem, a to $v$ př́padě hrozby dalšího odkladu plodnosti, která by však mohla být limitována vyšším věkem ženy.

Podobně jako byl identifikován sekvenční charakter plánování počtu dětí v průběhu života ženy (Rabušic - Chromková Manea 2007), tak je možné najít sekvenčnost i v časování plodnosti, kterou je možné identifikovat pomocí sekvenčnosti ve zdůvodnění odkladu. Na začátku reprodukčního období ženy hrají v plánování rodičovství nejsilnější roli individuální motivy jako vzdělání a realizace $\mathrm{v}$ zaměstnání. Tyto motivy vedou $\mathrm{v}$ důsledku $\mathrm{k}$ racionálnímu přehodnocení plánu stát se rodičem a ve zpětném pohledu nemusí být vnímány jako prŕčiny neplánovaného odkladu. Po této fázi může nastat partnersky motivovaný odklad, kdy žena bud'to nemá vhodného partnera, s nímž by založila rodinu, nebo se s partnerem v otázce časování rodičovství neshodne. Neshoda $\mathrm{s}$ partnerem pak může vést $\mathrm{k}$ rozpadu svazku, a celý partnersky motivovaný odklad tak začíná nanovo. $V$ poslední fázi, kdy je př́ípadný partnersky motivovaný odklad vyřešen, může nastat zdravotně motivovaný odklad. Partnersky a zdravotně motivovaný odklad již ve výpovědích respondentek vystupují jako př́činy neplánovaného odkladu.

Propojení výsledků kvantitativního a kvalitativního výzkumu umožnilo hlubší porozumění motivacím odkladu rodičovství, než jaké umožňuje samostatný výzkum kvantitativní nebo kvalitativní. Cílem bylo zhodnotit okolnosti, které mohou vést $\mathrm{k}$ neplánovanému odkladu. Ukazuje se, že př́rčiny neplánovaného odkladu závisí na věku a životní etapě respondentky. Neplánovanému odkladu častěji čelí ženy starší, které mají ukončené studium i pracovní zkušenosti. Výzkum zároveň poukázal na skutečnost, že samotné přehodnocení vlastního plánu nemusí ženy vnímat jako neplánovaný odklad, protože je výsledkem jejich volby. Neplánovaný odklad nastává, když už není rozhodnutí jen na nich a početí brání nějaké vnější okolnosti (neshoda s partnerem či zdravotní komplikace). Dále že u žen, které jsou zatím na začátku dospělosti, nemusí překonání aktuálních překážek (převážně v podobě jimi stanovených podmínek pro rodičovství) vést $\mathrm{k}$ následné snadné realizaci mateřství. Závěrem je nutné zmínit, že i přesto, že výpovědi informantek jsou hodnotným zdrojem informací, poznatky získané jejich prostřednictvím mohou být $\mathrm{v}$ důsledku svého retrospektivního charakteru zatíženy nedokonalostí paměti či proměnou vnímání popisované situace, které mohou s časovým odstupem narůstat. Navíc výpovědi omezeného vzorku dotazovaných žen nemohou zachytit všechny možné důvody odkladu mateřství. Lze očekávat, že některé důvody, které jako neplánované nebyly hodnoceny, mohou nastat i neplánovaně. Např́íklad žena 
začne studovat na základě požadavku zaměstnavatele, aby si udržela pracovní pozici, a neplánovaně tím musí odložit své mateřství.

Jitka Slabá je studentkou doktorského programu Demografie na Katedře demografie a geodemografie PřF UK. Ve své disertační práci se detailněji zaměřju na odklad mateřství u českých žen, především na jeho zdůvodnění.

Jiřina Kocourková je docentkou demografie a vedouci Katedry demografie a geodemografie na PřF UK. Věnuje se analýze reprodukčního chováni a jeho souvislostí, plánovanému rodičovství a otázkám rodinné politiky. V letech 2015 - 2017 působila v odborné komisi rodinné politiky MPSV ČR.

Anna Št'astná je demografka a socioložka. Od roku 2004 pracuje ve Výzkumném ústavu práce a sociálních věci, v.v.i. v pracovni skupině rodinné politiky a od roku 2015 na Katedře demografie a geodemografie PřF UK jako vědecká pracovnice. Výzkumnou činnost zaměruje především na reprodukčni chování, sociologii rodiny a rodinnou politiku.

\section{LITERATURA}

AINSAAR, M. - PAAJANEN, P., 2009: Resource, Life Stage and Partner-Related Reasons of Postponement of Births: Comparison of Estonia and Finland. TRAMES: A Journal of the Humanities \& Social Sciences 13(2): 109-128. https://doi.org/10.3176/tr.2009.2.02

AJZEN, I. - KLOBAS, J., 2013: Fertility Intentions: An Approach Based on the Theory of Planned Behavior. Demographic research 29: 203-232. https://doi.org/10.4054/DemRes.2013.29.8

BEGALL, K., 2013: How do Educational and Occupational Resources Relate to the Timing of Family Formation? A Couple Analysis of the Netherlands. Demographic Research 29(34): 907-936. https://doi.org/10.4054/DemRes.2013.29.34

BERRINGTON, A., 2004: Perpetual Postponers? Women's, Men's and Couple's Fertility Intentions and Subsequent Fertility Behaviour. Population trends 117: 919. Dostupné na: https://pdfs.semanticscholar.org/734a/d86ccd724d1703205848810 6579616fd9ed4.pdf

BERRINGTON, A., 2017: Childlessness in the UK. In: M. Kreyenfeld \& D. Konietzka: Childlessness in Europe: Contexts, Causes, and Consequences, MPIDR, Rostock, s. 57-76. https://doi.org/10.1007/978-3-319-44667-7

COOKE, A. - MILLS, T. A. - LAVENDER, T., 2012: Advanced Maternal Age: Delayed Childbearing is Rarely a Conscious Choice: A Qualitative Study of Women's Views and Experiences. International journal of nursing studies 49(1): 3039. https://doi.org/10.1016/j.ijnurstu.2011.07.013

DANILUK, J. C. - KOERT, E., 2017: Between a Rock and a Hard Place: The Reasons why Women delay Childbearing. International Journal of Healthcare 3(1): 76-83. https://doi.org/10.5430/ijh.v3n1p76 
DEL BONO, E. - WEBER, A. - WINTER-EBMER, R., 2015: Fertility and Economic Instability: The Role of Unemployment and Job Displacement. Journal of Population Economics 28(2): 463-478. https://doi.org/10.1007/s00148-014-0531-y

DOMMERMUTH, L. - KLOBAS, J. - LAPPEGÅRD, T., 2011: Now or Later? The Theory of Planned Behavior and Timing of Fertility Intentions. Advances in life course research 16(1): 42-53. https://doi.org/10.1016/j.alcr.2011.01.002

DUDOVÁ, R., 2020: „Je to o tom, koho potkáš“: Jednodětnost ve světle spojených životních drah. Sociologický časopis / Czech Sociological Review 56(2): 165-195. https://doi.org/ 10.13060/csr.2020.006

DEY, I. - FRAN, W., 2010: Another Child? Fertility Ideals, Resources and Opportunities. Population Research and Policy Review 29(6): 921-940. https://doi.org/10.1007/s11113-009-9174-1

ESPING-ANDERSEN, G., 2017: Education, Gender Revolution, and Fertility Recovery. Vienna yearbook of population research 15: 55-59. https://doi.org/10.1553/populationyearbook2017s055

ESTEVE, A., - TREVINO, R., 2019: The Main Whys and Wherefores of Childlessness in Spain. Perspective Demografiques 15: 1-4. Dostupné na: https://ced.uab.cat/PD/PerspectivesDemografiques_015_ENG.pdf

FREJKA, T., 2008: Birth Regulation in Europe: Completing the Contraceptive Revolution. Demograpic Research 19(5): 73-84. https://doi.org/10.4054/DemRes.2008.19.5

GEMMILL, A., 2019: From Some to None? Fertility Expectation Dynamics of Permanently Childless Women. Demography 56: 129-149. https://doi.org/10.1007/s13524-018-0739-7

HARTNETT, C. S. - MARGOLIS, R., 2019: Births that are Later-thna-Desired: Correlates and Consequences. Population Research and Policy Review 38: 483-505. https://doi.org/10.1007/s11113-019-09513-6

HAŠKOVÁ, H., 2009: Fenomén bezdětnosti. Praha: Sociologické nakladatelství SLON. 267 s. ISBN 978-80-7419-020-9.

HAŠKOVÁ, H. - DUDOVÁ, R., 2014: Kvantitativní a kvalitativní přístupy ve výzkumu životních drah. SDA Info 8(1): 5-24. https://doi.org/10.13060/23362391.2014.8.1.112

HAYFORD, S., 2009: The Evolution of Fertility Expectation Over the Life Course. Demography 46(4): 765-783. https://doi.org/ 10.1353/dem.0.0073

HOFÄCKER, D. - CHALOUPKOVÁ, J., 2014: Patterns of Family Life Courses in Europe - between Standardisation and Diversity. A Cross-national Comparison of Family Trajectories and Life Course Norms in European Countries. Comparative Population Studies 39(3): 559-586. http://doi.org/10.12765/CPoS-2014-11en

KAPITÁNY, B. - SPÉDER, Z., 2012: Realization, Postponement or Abandonment of Childbearing Intentions in four European Countries. Population 67(4): 599-629. https://doi.org/10.2307/23391586

KOCOURKOVÁ, J. - FAIT, T., 2011: Changes in Contraceptive Practice and the Transition of Reproduction Pattern in the Czech Population. The European Journal of Contraception and Reproductive Health Care 16(2): 161-172. https://doi.org/10.3109/13625187.2011.574750. 
KOCOURKOVÁ, J. - ŠŤASTNÁ, A., 2021: The Realization of Fertility Intentions in the Context of Childbearing Postponement: Comparison of Transitional and PostTransitional Populations. Journal of Biosocial Science 53(1): 82-97. https://doi.org/10.1017/S002193202000005X

KOHLER, H. P. - BILLARI, F. C. - ORTEGA, J. A., 2002: The Emergence of Lowest-Low Fertility in Europe during the 1990s. Population and development review 28(4): 641-680. https://doi.org/10.1111/j.1728-4457.2002.00641.x

KŘESŤANOVÁ, J. - KURKIN, R., 2019: Populační vývoj v České republice v roce 2018. Demografie 61(3): 190-210. Dostupné na: https://www.czso.cz/documents/10180/91917738/13005319q3_190.pdf/1e9753a247a5-4ea1-a027-aecaa2b4c2ad?version $=1.1$

KURKIN, R. - ŠPROCHA, B. - ŠÍDLO, L. - KOCOURKOVÁ, J., 2018: Fertility Factors in Czechia According to the Results of the 2011 Census. AUC Geographica 53(2): 137-148. https://doi.org/ 10.14712/23361980.2018.14

KYZLINKOVÁ, R. - ŠŤASTNÁ, A., 2016: Reprodukční plány mladých mužů v ČR. Demografie 58(2): 111-128.

KYZLINKOVÁ, R. - ŠŤASTNÁ, A., 2018: Fatherhood in a Changing Society: Shifts in Male Fertility Patterns. Sociological Research Online 23(2): 328-353. https://doi.org/10.1177/1360780418754565

LECHNEROVÁ, Z., 2011: Determinanty oddalování početí dítěte. Sociální studia 4: 87-104. https://doi.org/10.5817/SOC2011-4-87

LESTHAEGHE, R., 2010: The Unfolding Story of the Second Demographic Transition. Population and development review 36(2): 211-251. https://doi.org/10.1111/j.1728-4457.2010.00328.x

McDONALD, P., 2000: Gender Equity in Theories of Fertility Transition. Population and Development Review 26(3): 427-439. https://doi.org/10.1111/j.17284457.2000.00427.x

MIETTINEN, A. - PAAJANEN, P., 2005: Yes, No, Maybe: Fertility Intentions and Reasons Behind Them Among Childless Finnish Men and Women. Yearbook of Population Research in Finland 41: 165-184. Dostupné na: https://journal.fi/fypr/article/view/45020/11298

MIKOLAI, J. - BERRINGTON, A. - PERELlI-HARRIS, B., 2018: The Role of Education in the Intersection of Partnership Transitions and the Motherhood in Europe and the United States. Demographic Research 39(27): 753-794. https://doi.org/10.4054/DemRes.2018.39.27

MILLS, M. - RINDFUSS, R. R. - McDONALD, P. - TE VELDE, E., 2011: Why do People Postpone Parenthood? Reasons and Social Policy Incestives. Human Reproduction Update 17(6): 848-860. https://doi.org/10.1093/humupd/dmr026

MYNARSKA, M., 2010: Deadline for Parenthood: Fertility Postponement and Age Norms in Poland. European Journal of Population 26: 351-373. https://doi.org/10.1007/s10680-009-9194-x

NEELS, K. - MURPHY, M. - NÍ BHROLCHÁIN, M. - BEAUJOUAN, É., 2019: Rising Educational Participation and the Trends to Later Childbearing. Population and Development Review 43(4): 667-693. https://doi.org/10.1111/padr.12112 
NÍ BHROLCHÁIN, M. - BEAUJOUAN, É., 2012: Fertility Postponement is Largely Due to Rising Educational Enrolment. Population studies 66(3): 311-327. https://doi.org/10.1080/00324728.2012.697569

ONWUEGBUZIE, A. J. - COLLINS, K. M., 2007: A Typology of Mixed Methods Sampling Designs in Social Science Research. The Qualitative Report 12: 281-316.

PERELLI-HARRIS, B. - SIGLE-RUSHTON, W. - KREYENFELD, M. - LAPPEGARD, T. - KEIZER, R. - BERGHAMMER, C., 2010: The Educational Gradient of Childbearing within Cohabitation in Europe. Population and Development Review 36(4): 775-801. https://doi.org/10.2307/25749225

POLESNÁ, H. - KOCOURKOVÁ, J., 2016: Je druhý demografický přechod stále relevantní koncept pro evropské státy? Geografie 121(3): 390-418.

RABUŠIC, L. - CHROMKOVÁ MANEA, B.-E., 2007: Jednodětnost v českých rodinách. Kdo jsou ti, kdo mají nebo plánují pouze jedno dítě. Sociologický časopis 43(4): 699-719. https://doi.org/ 10.13060/00380288.2007.43.4.03

REGUSHEVSKAYA, E. - HEMMINKI, E. - KLEMETTI, R. - ROTKIRCH, A. KARRO, H. - HAVVIO-MANNILA, E. - MIETTINEN, A., 2013: Postponing Births - Comparing Reasons Among Women in St Petersburg, Estonia and Finland. Finnish Yearbook of Population Research XLVIII, s. 127-145. Dostupné na: https://journal.fi/fypr/article/view/40932/10231

SIVKOVÁ, O. - HULÍKOVÁ TESÁRKOVÁ, K., 2012: Dekompozice změn průměrného věku matky při narození dítěte v České republice od roku 1950. Demografie 54(3): 264-279. Dostupné na:

https://www.czso.cz/documents/10180/20555359/e-180312q3.pdf/62e9767a-5a6140f3-baae-c0528427c1d7?version=1.0

SLABÁ, J., 2020: Nezaměstnanost ženy jako příčina deklarovaného odkladu založení rodiny? Sociológia 52(2): 132-152. https://doi.org/10.31577/sociologia.2020.52.2.6

SLEPIČKOVÁ, L. - BARTOŠOVÁ, M., 2008: Problematické tranzice k mateřství. Sociální studia 2: 35-54. https://doi.org/10.5817/SOC2008-2-35

SOBOTKA, T. - ZEMAN, K. - LESTHAEGHE, R. - FREJKA, T. 2011: Postponement and recuperation in cohort fertility: New analytical and projection methods and their application. European Demographic Research Papers 2. Vienna: Vienna Institute of Demography.

SOBOTKA, T., 2017: Post-Transitional Fertility: The Role of Childbearing Postponement in Fuelling the Shift to Low and Unstable Fertility Levels. Journal of Biosocial Science 49(S1): S20-S45. https://doi.org/10.1017/S0021932017000323

ŠPROCHA, B. 2014: Odkladanie a rekuperácie plodnosti v kohortnej perspektíve v Českej republike a na Slovensku. Demografie 56(3): 219-233.

ŠPROCHA, B. - TIŠLIAR, P. - ŠÍDLO, L., 2018: A Cohort Perspective on the Fertility Postponement Transition and Low Fertility in Central Europe. Moravian geographical reports 26(2): 109-120. https://doi.org/10.2478/mgr-2018-0009

ŠPROCHA, B. - ŠÍDLO, L., 2018: Vývoj reprodukčného správania v Českej republike a v Slovenskej republike v 20. storočí a na začiatku 21. storočia. Slovenská štatistika a demografia 3: 25-43. 
ŠŤASTNÁ, A. - SLABÁ, J. - KOCOURKOVÁ, J., 2017: Plánování, načasování a důvody odkladu narození Prvního dítěte v České republice. Demografie 59(3): 207223. Dostupné na: https://www.czso.cz/documents/10180/46203816/stastna.pdf/0cf15559-1e0a-4b47a7d6-e8faeb236404?version $=1.0$

ŠŤASTNÁ, A. - SLABÁ, J. - KOCOURKOVÁ, J., 2019: Druhé dítě - důvody neplánovaného odkladu a časování jeho narození. Demografie 61(2): 77-92. Dostupné na:https://www.czso.cz/documents/10180/91917740/13005319q2_77.pdf/b0972342 -7094-4feb-bf85-f0acb04e1f30?version=1.0

ŠŤASTNÁ, A. - KYZLINKOVÁ, R., 2019: Vzdělání a přechod k otcovství v České republice: reflexe dvou společenských kontextů. Sociológia 51(4): 393-419. https://doi.org/10.31577/sociologia.2019.51.4.18

TOULEMON, L. - TESTA, M. R., 2005: Fertility Intentions and Actual Fertility: A Complex Relationship. Population \& societies 4: 1-4. Dostupné na: https://pdfs.semanticscholar.org/62a8/d2021a2e50905aab3ff028c479e6664dfca5.pd f?_ga $=2.163077884 .1371297835 .1589890037-788640204.1583936562$

VAN DE KAA, D. J., 1997: Options and Sequences: Europe's Demographic Patterns. Journal of Population Research 14(1): 1-29. https://doi.org/10.1007/BF03029484

VÍTEČKOVÁ, M. - KLÍMOVÁ CHALOUPKOVÁ, J., 2014: Destandardizace rodinných drah: rodičovství v nesezdaném soužití jako alternativa i cesta $\mathrm{k}$ manželství. Kontakt 2: 163-173. https://doi.org/10.1016/j.kontakt.2014.05.001

WALFORD, N. - KUREK, S., 2016: Outworking of the Second Demographic Transition: National Trends and Regional Patterns of Fertility Change in Poland, and England and Wales, 2002 - 2012. Population, Space and Place 22(6): 508-525. https://doi.org/10.1002/psp.1936

WIJSEN, A. C., 2002: Timing Children at a Later Age: Motivational, Behavioural, and Socio-Structural Differentials in the Individual Decision Making Process of Older Mothers. Amsterdam: Rozenberg Publishers. 